\title{
Indosinian magmatism and rare metal mineralization in East Tianshan orogenic belt: An example study of Jingerquan Li-Be-Nb-Ta pegmatite deposit
}

\author{
Siyu LIU ${ }^{1}$, Rui WANG ${ }^{1 *}$, Heejin JEON ${ }^{2}$
}

${ }^{1}$ State Key Laboratory of Geological Processes and Mineral Resources, and Institute of Earth Sciences, China University of Geosciences, Beijing 100083, China (*correspondence: rw@cugb.edu.cn)

${ }^{2}$ Swedish Museum of Natural History, Stockholm SE10405, Sweden

In Eastern Tianshan region, a large number of granites and granitic pegmatites intruded into Carbonaceous volcanic-sedimentary strata [1] and triggered a sequence of $\mathrm{Cu}-\mathrm{Au}-\mathrm{Fe}$ and rare-metal mineralization [2]. The Jingerquan Li-Be-Nb-Ta deposit is the largest pegmatite deposit in this region [3]. However, its mineralization age and petrogenesis is not well constrained. Two magmatic suites of Libearing granitoid group (Class I) and Li-poor gabbroic group (Class II) have been recognized in Jingerquan region. We have conducted two monazite SIMS U-Pb dating from Class I, which gave $246.0 \pm 2.0 \mathrm{Ma}$ and $252.9 \pm 1.9 \mathrm{Ma}$, respectively [4]. These mineralization ages are in good agreement with Class II crystallization ages of $247.6 \pm 1.2 \mathrm{Ma}$ to $250.7 \pm 2.5 \mathrm{Ma}$ [4].

Class I rocks are rich in $\mathrm{Si}, \mathrm{Al}, \mathrm{Na}, \mathrm{K}$, calcalkaline to high-K calc-alkaline series, and poor in $\mathrm{Ca}$, $\mathrm{P}, \mathrm{Fe}$, and $\mathrm{Mg}$, with $\mathrm{A} / \mathrm{CNK} \geq 1.1$, which are similar to S-type peraluminous granites. They are characterized by $\mathrm{Rb}, \mathrm{Ta}, \mathrm{Nb}$, Hf enrichments, significant $\mathrm{Ti}, \mathrm{Ba}, \mathrm{Sr}$ depletions, significant $\mathrm{Eu}$ anomalies $(\delta \mathrm{Eu}=0.01-0.20)$ and "tetrad effect". Class II rocks are calc-alkaline rocks that are rich in $\mathrm{Ca}, \mathrm{Al}$, and $\mathrm{P}$ and poor in $\mathrm{Si}, \mathrm{K}$, with $\mathrm{A} / \mathrm{CNK}<1$. They are characterized by $\mathrm{Ba}, \mathrm{Sr}$ enrichments, $\mathrm{Th}, \mathrm{Nb}$, Ta depletions, no significant $\mathrm{Eu}$ anomalies $(\delta \mathrm{Eu}=0.97-1.40)$, positive $\varepsilon \mathrm{Hf}(\mathrm{t})$ values (12.0-15.2) and juvenile $\mathrm{T}_{\mathrm{DM}}(279-411 \mathrm{Ma})$.

In the intraplate extensional setting, the mantle magmas represented by ClassII basaltic magmas intraplated into the crust and induced partial melting of the middle and upper crust to produce Class I S-type granitic magmas. After that, the granitic magmas underwent continuous differential evolution and volatile enrichment, and finally formed $\mathrm{Li}-\mathrm{Be}-\mathrm{Nb}-\mathrm{Ta}$ mineralized granitic pegmatite. The future $\mathrm{Li}-\mathrm{Be}-\mathrm{Nb}-$ Ta exploration should focus on Eastern Tianshan region where Indosinian magmas similar to Class I are widespread.

[1] Li et al. (2002) North western Geology 35, 41-64. [2] Han et al. (2018) Acta Petrologica Sinica 34, 19141932. [3] Chen et al. (2006) Mineral Deposits 25, 470476. [4] Liu et al. (2020) OGR 116, 103265. 